\title{
Gene expression markers of tendon fibroblasts in normal and diseased tissue compared to monolayer and three dimensional culture systems
}

\author{
Sarah E Taylor* ${ }^{* 1}$, Anne Vaughan-Thomas ${ }^{\dagger 1}$, Dylan N Clements ${ }^{\dagger 2}$, \\ Gina Pinchbeck ${ }^{\dagger 1}$, Lisa C Macrory ${ }^{\dagger 1}$, Roger KW Smith ${ }^{\dagger 3}$ and Peter D Clegg ${ }^{\dagger 1}$
}

Address: ${ }^{1}$ Department of Veterinary Clinical Science, University of Liverpool, Neston, South Wirral, CH64 7TE, UK, ${ }^{2}$ Royal (Dick) School of Veterinary Studies, University of Edinburgh, Easter Bush Veterinary Centre, Roslin, EH25 9RG, UK and ${ }^{3}$ Royal Veterinary College, Department of Veterinary Clinical Science, North Mymms, Northampton, UK

Email: Sarah E Taylor* - Sarah.Taylor@liv.ac.uk; Anne Vaughan-Thomas - avt4460@liverpool.ac.uk;

Dylan N Clements - Dylan.Clements@ed.ac.uk; Gina Pinchbeck - ginap@liverpool.ac.uk; Lisa C Macrory - lmacrory@liv.ac.uk;

Roger KW Smith - RkSmith@RVC.AC.UK; Peter D Clegg - p.d.clegg@liv.ac.uk

* Corresponding author †Equal contributors

Published: 26 February 2009

BMC Musculoskeletal Disorders 2009, 10:27 doi:10.1 186/1471-2474-10-27
Received: 27 October 2008

Accepted: 26 February 2009

This article is available from: http://www.biomedcentral.com//47I-2474//0/27

(c) 2009 Taylor et al; licensee BioMed Central Ltd.

This is an Open Access article distributed under the terms of the Creative Commons Attribution License (http://creativecommons.org/licenses/by/2.0), which permits unrestricted use, distribution, and reproduction in any medium, provided the original work is properly cited.

\begin{abstract}
Background: There is a paucity of data regarding molecular markers that identify the phenotype of the tendon cell. This study aims to quantify gene expression markers that distinguish between tendon fibroblasts and other mesenchymal cells which may be used to investigate tenogenesis.

Methods: Expression levels for 12 genes representative of musculoskeletal tissues, including the proposed tendon progenitor marker scleraxis, relative to validated reference genes, were evaluated in matched samples of equine tendon (harvested from the superficial digital flexor tendon), cartilage and bone using quantitative PCR (qPCR). Expression levels of genes associated with tendon phenotype were then evaluated in healthy, including developmental, and diseased equine tendon tissue and in tendon fibroblasts maintained in both monolayer culture and in three dimensional (3D) collagen gels.

Results: Significantly increased expression of scleraxis was found in tendon compared with bone $(P=0.002)$ but not compared to cartilage. High levels of COLIA2 and scleraxis and low levels of tenascin- $C$ were found to be most representative of adult tensional tendon phenotype. While, relative expression of scleraxis in developing mid-gestational tendon or in acute or chronically diseased tendon did not differ significantly from normal adult tendon, tenascin- $\mathrm{C}$ message was significantly upregulated in acutely injured equine tendon $(P=0.00 \mathrm{I})$. Relative scleraxis gene expression levels in tendon cell monolayer and $3 \mathrm{D}$ cultures were significantly lower than in normal adult tendon ( $P=0.002, P=0.02$ respectively).

Conclusion: The findings of this study indicate that high expression of both COLIA2 and scleraxis, and low expression of tenascin- $C$ is representative of a tensional tendon phenotype. The in vitro culture methods used in these experiments however, may not recapitulate the phenotype of normal tensional tendon fibroblasts in tissues as evidenced by gene expression.
\end{abstract}




\section{Background}

Tendon injuries are a significant cause of morbidity in both man and veterinary species and are reported to represent $30 \%$ of the musculoskeletal caseload in a one year study of human general practitioners [1]. Injury to the equine superficial digital flexor tendon (SDFT) poses a significant problem amongst racing Thoroughbreds with a reported incidence of $11-43 \%[2,3]$. The extracellular matrix (ECM) of flexor tendons has evolved not only to both transmit forces from muscle to bone but also as an elastic energy store for efficient locomotion [4]. However, once a tendon has been injured a fibrous repair response ensues which, whilst being very efficient at repairing the damaged tissue, does not regenerate the original tendon matrix [5]. The fibrous scar tissue does not recapitulate the unique parallel collagen fibre alignment found in normal tendon. Consequently, the healed tendon does not retain the biomechanical properties of the original tendon prior to injury [5] and re-injury rates in horses can be as high as $56 \%[6]$.

The poor clinical outcome associated with tendon injury and the limited capacity for regeneration of injured tendon have resulted in a growing interest in the use of tissue engineering approaches for tendon therapy in both man and animals [7]. Objective demonstration of successful regeneration requires the identification of markers of tenogenesis. However, currently there are no specific molecular markers that can be used to characterise tendon fibroblasts [8] and identify relevant differentiation and repair. Verification of the success of tendon tissue engineering interventions is currently based on histological analysis and mechanical testing [9]. Identification of pertinent gene expression would be beneficial in confirming cell differentiation to a relevant tendon cell phenotype. Expression of key matrix genes within tissue engineered constructs has also been used to identify such differentiation, although validation of the relevance of the candidate marker genes has not yet been performed [10]. Unfortunately many of these key matrix genes are expressed in a variety of mesenchymal tissues and therefore may not be sufficiently discriminatory. In contrast, the genes COL2A1, COL10A1 and SOX9 are well accepted as being representative of chondrogenic differentiation [11] and Runx2 and osteopontin are discriminating for osteogenic differentiation [11]. In the current study eleven genes were selected as representative of tendon, cartilage and bone and quantified in these musculoskeletal tissues to identify which of these genes were most discriminating for a tendon phenotype.

Collagen type I forms $95 \%$ of the collagen content of normal adult tendons, the remaining 5\% constitutes small amounts of collagen types III, V, VI, XII and XIV [12]. Following acute rupture of the human Achilles tendon or equine SDFT gene expression of collagen types I, III and V is increased [13-16]. Tenascin-C is also up regulated following tissue wounding [17] and in degenerate tendinopathy [18]. Other important tendon matrix components include the small leucine rich proteoglycans (lumican, decorin, biglycan and fibromodulin). The role of these smaller matrix components has been demonstrated to be important in collagen fibrillogenesis [19]. In addition the glycoproteins such as cartilage oligomeric matrix protein (COMP) and tenascin- $\mathrm{C}$ are understood to be involved in collagen fibrillogenesis [20-22].

COMP is an extracellular matrix glycoprotein that is abundant in tissues subjected to load. Levels of COMP increase until skeletal maturity is reached after which time levels gradually decline [20]. Tenomodulin is a type II transmembrane glycoprotein that is preferentially expressed in dense connective tissues. Mice lacking tenomodulin have tendons with a disrupted fibril structure and exhibit severely reduce tendon fibroblast proliferation [23]. Tenomodulin has been reported to be a good phenotype marker for tendon fibroblasts [24]. Decorin is a member of the SLRPs that have been shown to be important in control of collagen fibrillogenesis [25]. Recent investigations have highlighted scleraxis as a specific marker of tendon progenitor cells [26-28]. Furthermore, scleraxis null mutant mice have distinct tendon defects [26]. Runx2 is an osteogenic transcription factor [11]. Osteopontin is a glycoprotein found in bone and forms part of the inorganic component of bone. Osteomodulin is a keratan sulphate proteoglycan found in the ECM of bone and thought to be a marker of osteoblast maturation [29]. SOX9 is a transcription factor important in chondrocyte regulation and is frequently used to identify chondrogenic differentiation [11].

The study performed here was designed to identify the presence of the eleven genes in normal tendon and quantify their expression levels in tendon compared to other musculoskeletal tissues. The expression of key genes which could identify an adult tendon phenotype were then characterised both in clinical cases of tendinopathy of the equine SDFT, as well as during development. Furthermore the expression profile of these genes was characterised in-vitro in both monolayer and three dimensional (3D) cultures of tendon fibroblasts to identify whether such models fully recapitulate the tendon phenotype.

\section{Methods \\ Tissue samples}

Tissue samples were obtained from animals subjected to euthanasia for clinical reasons other than orthopaedic disease. Full informed written consent was obtained from animal owners for all tissue collection and tissue collection was subject to ethical review. Three samples $(10 \times 5 \times$ 
$2 \mathrm{~mm}$ ) of equine superficial digital flexor tendon were obtained from the mid-metacarpal region from skeletally mature (aged 4-10 years) horses free of clinical orthopaedic disease. Matched cartilage samples $(10 \times 3 \times 0.5 \mathrm{~mm})$ were harvested from the articular surface of the distal aspect of the third metacarpal bone of the same donors with bone $(10 \times 5 \times 2 \mathrm{~mm})$ being harvested from the distal metacarpal epiphysis. Further samples were collected from five skeletally immature animals (three mid-gestational foetuses and two yearlings). All tissue specimens were grossly normal on post mortem examination. Pathological tissue specimens were collected from the mid-metacarpal region of the SDFT of 3 horses with acute $(<6$ weeks duration) and 3 horses with chronic ( $>6$ months duration) tendinopathy. All samples were obtained within 4 hours of euthanasia and collected into RNAlater $^{\mathrm{TM}}$ (Ambion, Applied Biosystems). Samples were stored at $4{ }^{\circ} \mathrm{C}$ for 24 hours and then frozen at $-80^{\circ} \mathrm{C}$ until used for RNA extraction.

\section{Monolayer cell culture}

For the cell culture experiments tendon samples were collected from 4 adult (age 4-10 yrs), mixed breed horses subjected to euthanasia. All tendons were free of pathology on clinical and post mortem examination. Tendons were collected from the SDFT at the level of the mid-metacarpus (tensional), within 4 hours of euthanasia. Samples were cut into $2 \times 2 \times 2 \mathrm{~mm}^{3}$ pieces and subjected to collagenase type II $(0.1 \%)$ digestion overnight in DMEM (Sigma) containing 5\% FCS, penicillin/streptomycin and amphotericin) on an orbital shaker at $37^{\circ} \mathrm{C}$. The isolated tendon fibroblasts were cultured in $75 \mathrm{~cm}^{2}$ flasks in DMEM containing 10\% FCS, penicillin/streptomycin and fungizone at $5 \% \mathrm{CO}_{2}$ and $37^{\circ} \mathrm{C}$ until approximately $90 \%$ confluent before passaging (usually 4-6 days for each passage). Cells were released from flasks with trypsin $(0.05 \%)$ and re-seeded into flasks at 5000 cells $/ \mathrm{cm}^{2}$. Culture medium was changed every 3-4 days. One millilitre of Tri-Reagent (Sigma) was added to the remaining cells for subsequent RNA extraction, these samples were stored at $-80^{\circ} \mathrm{C}$. The cells were passaged 5 times for the 3 different horses.

\section{Three dimensional cell culture in collagen gels}

Tendon fibroblasts harvested from the tensional area of the SDFT as described above were cultured until confluent. Collagen gels were prepared following a method described previously [30]. Briefly, following trypsinisation at the end of passage one, cells were counted and suspended in $90 \%$ type I collagen gel $(2 \mathrm{mg} / \mathrm{ml})$ (Invitrogen), $10 \% 10 \times \operatorname{DMEM}$ (Sigma) using $1 \times 10^{6}$ cells $/ \mathrm{mL}$. Two hundred microlitres of the collagen cell suspension were cast in a trough mold (Trough loader, Flexcell International) centrally located in a Tissue train culture plate (Flexcell International). The collagen gels were cultured at
$5 \% \mathrm{CO}_{2}$ in a humidified incubator at $37^{\circ} \mathrm{C}$ for 24 hours prior to the addition of DMEM containing $10 \%$ FCS, penicillin/streptomycin and amphotericin. Cell seeded collagen gels were then cultured without dynamic load for 5 days.

\section{RNA extraction and quantification}

RNA was extracted using phenol/guanidine $\mathrm{HCl}$ reagents (TriReagent ${ }^{\mathrm{TM}}$, Sigma) and isolated using the published methods [31,32]. Tissue samples were pulverised for 1 minute at 2000 oscillations/minute in a liquid nitrogen cooled dismembranator (Braun Mikro-Dismembrator Vessel, Braun Biotech International, Melsungen, Germany). A $1 \mathrm{~mL}$ aliquot of phenol/guanidine $\mathrm{HCl}$ reagents (TriReagent ${ }^{\mathrm{TM}}$, Sigma) was added to the powdered tendon, cartilage or bone. Two hundred microlitres of chloroform was added to the microcentrifuge tubes prior to centrifugation at $12,000 \mathrm{~g}$ for 10 minutes. RNA was extracted from the aqueous phase using a commercially available RNA purification kit (RNeasy Mini Kit, Qiagen). Digestion of DNA was carried out using a commercially available kit (RNase-Free DNase Set, Qiagen). RNA was stored at $80^{\circ} \mathrm{C}$ prior to reverse transcription.

\section{Reverse transcription}

The purified RNAs were measured (ND-1000 spectrophotometer Nanodrop Technologies) and then $1 \mu \mathrm{g}$ RNA was used to prepare cDNA using M-MLV reverse transcriptase and random primers according to the manufacturer's instructions (Promega). Samples were stored at $-20^{\circ} \mathrm{C}$ prior to relative quantification of gene expression.

\section{Primer Design}

Transcript sequences were obtained from the National Centre for Biotechnology Information (Bethesda, MD, USA) (Tables 1 \&2). Equine gene sequences were aligned to human, bovine and canine sequences using online software (http://www.ebi.ac.uk/Tools/clustalw/, http:// www.ensembl.org/) to predict exon boundaries. Primers were designed using Primer Express (Applied Biosystems) software and selected to span predicted exon boundaries where possible. BLAST searches were performed for all sequences to confirm gene specificity. Target and reference gene primers were synthesized by Eurogentec. All primers were validated using a standard curve of five serial dilutions so that all primer efficiencies were between 95105\% (Tables 1 and 2).

\section{Normalisation of reference genes}

The most stable pair of reference gene primers were selected using the normalization strategy proposed by [33]. Verification of reference gene selection was carried out using Normfinder [34]. Reference gene stability packages were downloaded from geNorm: http:// 
Table I: Reference gene primer sequences used for qPCR

\begin{tabular}{|c|c|c|c|}
\hline Gene & SCS & Efficiency (\%) & Sequence \\
\hline $\begin{array}{l}\text { GapDH } \\
\text { AFI57626 }\end{array}$ & -3.32 & 100.2 & $\begin{array}{l}\text { 5'GCATCGTGGAGGGACTCA3' } \\
\text { 3'GCCACATCTTCCCAGAGG5' }\end{array}$ \\
\hline $\begin{array}{l}18 \mathrm{~S} \\
\mathrm{AJ} 311673\end{array}$ & -3.24 & 103.3 & $\begin{array}{l}\text { 5'GGCGTCCCCCAACTTCTTA3' } \\
\text { 3'GGGCATCACAGACCTGTTATTG5' }\end{array}$ \\
\hline $\begin{array}{l}\text { ACTB } \\
\text { AF035774 }\end{array}$ & -3.33 & 99.9 & $\begin{array}{l}\text { (Bogaerts et al., 2006) } \\
\text { 5'CCAGCACGATGAAGATCAAG3' } \\
\text { 3'GTGGACAATGAGGCCAGAAT5' }\end{array}$ \\
\hline $\begin{array}{l}\text { SDHA } \\
\text { DQ402987 }\end{array}$ & -3.29 & 101.5 & $\begin{array}{l}\text { 5'ACAGAGGAATGGTCTGGAATACTGA3' } \\
\text { 3' GTGAGCACCACGTGACTCCTT5' }\end{array}$ \\
\hline
\end{tabular}

SCS $=$ Standard Curve Slope

medgen.ugent.be/ jjvdesomp/genorm/ and Normfinder: http://www.mdl.dk/publicationsnormfinder.htm/.

\section{RT-PCR}

Real time RT (qPCR) assays were performed in triplicate using the 7900 HT Fast Real-Time PCR System (Applied Biosystems; Warrington, UK) in 384 well plates. Reaction volume in each well was $10 \mu \mathrm{l}(4.6 \mu \mathrm{l}$ of cDNA, $5 \mu \mathrm{l}$ of Power SYBR mastermix (Applied Biosystems), $0.1 \mu \mathrm{l}$ of DEPC water $0.15 \mu \mathrm{l}$ of $3 \mu \mathrm{M}$ forward primer and $0.15 \mu \mathrm{l}$ of $3 \mu \mathrm{M}$ reverse primer). The cycling conditions comprised $10 \mathrm{~min}$ polymerase activation at $95^{\circ} \mathrm{C}$ and 40 cycles at $95^{\circ} \mathrm{C}$ for $15 \mathrm{sec}$ and $60^{\circ} \mathrm{C}$ for $60 \mathrm{sec}$. Data was then analysed using Sequence Detection Systems Software v2.2.1 (Applied Biosystems; Warrington, UK).

\section{Statistical analyses}

All data were presented as mean \pm SE. All data departed from normality and were therefore $\log _{10}$ transformed. Significant differences in gene expression between cartilage, tendon and bone matched samples were identified using a mixed effects linear regression model to allow for the clustering of samples within individual horses (S-Plus software). Comparisons between gene expression of normal tissue and developing or diseased or cultured cells were carried out using a two sample student's t-test where

Table 2: Target gene primer sequences use for qPCR

\begin{tabular}{|c|c|c|c|}
\hline Gene & SCS & Efficiency (\%) & Sequence \\
\hline $\begin{array}{l}\text { COLIA2 } \\
\text { XM_001492962 }\end{array}$ & -3.31 & 100.5 & $\begin{array}{l}\text { 5'GCACATGCCGTGACTTGAGA3' } \\
\text { 3'CATCCATAGTGCATCCTTGATTAGG5' }\end{array}$ \\
\hline $\begin{array}{l}\text { COL2AI } \\
\text { NM_00I08I764 }\end{array}$ & -3.21 & 105.0 & $\begin{array}{l}\text { 5'TCAAGTCCCTCAACAACCAGATC3' } \\
\text { 3'GTCAATCCAGTAGTCTCCGCTCTT5' }\end{array}$ \\
\hline $\begin{array}{l}\text { COL3AI } \\
\text { XM_00I50I7I9 }\end{array}$ & -3.22 & 104.6 & $\begin{array}{l}\text { 5'ACGCAAGGCCGTGAGACTA3' } \\
\text { 3'TGATCAGGACCACCAACATCA5' }\end{array}$ \\
\hline $\begin{array}{l}\text { COLIOAI } \\
\text { XM_00I504I0I }\end{array}$ & -3.39 & 97.4 & $\begin{array}{l}\text { 5'TGCCCAGTGGACAGGTTTCT 3' } \\
\text { 3'GTCTTTTCGTTTCTAGTCAGATTTTGAA5' }\end{array}$ \\
\hline $\begin{array}{l}\text { COMP } \\
\text { AF325902 }\end{array}$ & -3.42 & 95.7 & $\begin{array}{l}\text { 5'GGTGCGGCTGCTATGGAA3' } \\
\text { 3'CCAGCTCAGGGCCCTCAT5' }\end{array}$ \\
\hline $\begin{array}{l}\text { DCN } \\
\text { ABI06279 }\end{array}$ & -3.31 & 100.1 & $\begin{array}{l}\text { 5'CATCCAGGTTGTCTACCTTCATAACA3' } \\
\text { 3'CCAGGTGGGCAGAAGTCATT5' }\end{array}$ \\
\hline $\begin{array}{l}\text { TNC } \\
\text { XR_035757 }\end{array}$ & -3.36 & 98.6 & $\begin{array}{l}\text { 5'GGGCGGCCTGGAAATG3' } \\
\text { 3'CAGGCTCTAACTCCTGGATGATG5' }\end{array}$ \\
\hline $\begin{array}{l}\text { TMD } \\
\text { AB059407 }\end{array}$ & -3.38 & 97.4 & $\begin{array}{l}\text { 5'ACGTGACCATGTATTGGATCAATC3' } \\
\text { 3'CACCATCCTCCTCAAAGTCTTGT5' }\end{array}$ \\
\hline $\begin{array}{l}\text { SIXI } \\
\text { XM_00I492786 }\end{array}$ & -3.23 & 104.0 & $\begin{array}{l}\text { 5' GATGCCCCAATGTTTGTGATG3' } \\
\text { 3' AGGAGGCATTGCTGACAATCTT5' }\end{array}$ \\
\hline $\begin{array}{l}\text { SCXB } \\
\text { NM_001105150 }\end{array}$ & -3.35 & 98.8 & $\begin{array}{l}\text { 5'TCTGCCTCAGCAACCAGAGA3' } \\
\text { 3'TCCGAATCGCCGTCTTTC5' }\end{array}$ \\
\hline $\begin{array}{l}\text { SOX9 } \\
\text { XM_001498424 }\end{array}$ & -3.33 & 99.9 & $\begin{array}{l}\text { 5' CTTTGGTTTGTGTTCGTGTTTTGT3' } \\
\text { 3'AGAGAAAGAAAAAGGGAAAGGTAA GTTT5' }\end{array}$ \\
\hline $\begin{array}{l}\text { OPN } \\
\text { XM_001496152 }\end{array}$ & -3.33 & 99.9 & $\begin{array}{l}\text { 5'CGCAGATCTGAAGACCAGTATCCT3' } \\
\text { 3'TGCTTTCCACAGGTGATGTGA5' }\end{array}$ \\
\hline $\begin{array}{l}\text { RUNX2 } \\
\text { XM_001502519 }\end{array}$ & -3.36 & 98.4 & $\begin{array}{l}\text { 5'CTGGGCCATGTGTATGATTTGT3' } \\
\text { 3'TTTTGACCTGATATAGAGTGCATGGT5' }\end{array}$ \\
\hline $\begin{array}{l}\text { OMD } \\
\text { XR_035840 }\end{array}$ & -3.26 & 103.4 & $\begin{array}{l}\text { 5'CAAATTCATCAACCCCTGAAA3' } \\
\text { 3'CTTCATCTGGCTCTTGGTCA5' }\end{array}$ \\
\hline
\end{tabular}


log transformed data were normally distributed. The level of significance was set at $\mathrm{P}<0.05$.

\section{Results}

\section{Normalisation of reference genes}

GeNorm and Normfinder identified Glyceraldehyde -3phosphate dehydrogenase (GapDH) and succinate dehydrogenase subunit A (SDHA) to be the two most stably expressed reference genes across normal tendon, cartilage and bone samples, and both the $2 \mathrm{D}$ and $3 \mathrm{D}$ in vitro cultures $(M=0.045, V=0.027)$. The most stably expressed reference genes in tendon development and disease were beta actin (ACTB) and GapDH (M = 0.056, V = 0.057) (Table 3). When all samples were considered together GapDH was identified as the most stable gene (Normfinder ratio 0.050) and ACTB the second most stable gene (Normfinder ratio 0.072) (Table 3). GeNorm identified GapDH and ACTB to be the most stable pair of reference genes $(M=0.127, \mathrm{~V}=0.048)$ (Table 3$)$. As geNorm and Normfinder were in agreement, gene expression data was normalised to the average expression of GapDH and ACTB. The average Ct values used to identify the most stable reference genes can be seen in Additional file 1.

\section{Tissue samples \\ Adult mesenchymal tissues}

Figure 1 shows the data obtained for expression levels of genes presumed to be associated with tendon (a), bone (b) and cartilage (c). Scleraxis showed significantly higher expression in tendon than in bone $(\mathrm{P}=0.002)$ (Figure. 1a), and whilst higher levels of expression were identified in tendon than cartilage this did not reach statistical significance. As expected, significantly higher COL1A2 was expressed in both tendon and bone than in cartilage $(\mathrm{P}=$ 0.01 and $\mathrm{P}=0.008$, respectively) (Figure $1 \mathrm{a}$ ). Tenomodulin was identified in both tendon and bone but could not be detected in cartilage. No significant difference could be identified in the levels tenomodulin expression in tendon and bone. Tenascin-C expression was significantly lower in tendon than in bone $(P=0.02)$. COMP expression was significantly higher in tendon than in bone $(P=0.02)$ but no difference in expression was identified between tendon and cartilage (Figure. 1a). Decorin expression was highest in cartilage $(\mathrm{P}=0.03)$ and lowest in bone $(\mathrm{P}=$ $0.02)$. Osteopontin, Runx 2 and osteomodulin were able to discriminate between tendon and bone $(\mathrm{P}=0.003, \mathrm{P}=$ 0.03 and $\mathrm{P}=0.01$, respectively) (Figure. $1 \mathrm{~b}$ ) but Runx2 was the only hypothesised bone marker that distinguished between bone and cartilage $(\mathrm{P}=0.007)$. Of the cartilaginous markers, only COL2A1 was significantly lower in tendon than in both bone and cartilage $(\mathrm{P}=$ 0.005 and $P=0.0003)$. Cartilage showed higher expression of COL10A1 and SOX9 than tendon $(\mathrm{P}=0.01$ and $\mathrm{P}$ $=0.005$ respectively) (Figure. 1c). From the matched normal tissue samples a panel of COL1A2, scleraxis and tenascin- $\mathrm{C}$ were selected as the most discriminating genes of tendon phenotype.

\section{Tendon development}

Expression of COL1A2 was higher in the foetal tissues compared to mature tendon relative to reference gene mRNA $(P=0.01)$. There was increased tenascin-C expression in skeletally immature tendon in comparison to adult tendon $(P=0.02)$ (Figure. 2a).

\section{Tendon disease}

Acute tendinopathy produced significant changes in gene expression. Tenascin-C expression was greatly increased in acutely diseased tendon in comparison to normal tendon $(P=0.0001)$, although expression of scleraxis and COL1A1 did not vary. Chronic tendinopathy resulted in a gene expression profile similar to that of normal tissue with no significant difference in the expression of tenascin-C (Figure. 2b).

Table 3: $M$ and $V$ values generated by geNorm and Normfinder

\begin{tabular}{|c|c|c|c|c|}
\hline Sample & $\begin{array}{l}\text { Reference } \\
\text { Genes }\end{array}$ & $\begin{array}{l}\text { M Value } \\
\text { (Gene stability) }\end{array}$ & $\begin{array}{l}\text { V Value } \\
\text { (Pairwise stability) }\end{array}$ & Normfinder \\
\hline Tissue & $\begin{array}{l}\text { GapDH } \\
\text { SDHA }\end{array}$ & 0.045 & 0.027 & $\begin{array}{l}0.012 \\
0.018\end{array}$ \\
\hline $\begin{array}{l}\text { Developing } \\
\text { Tissue }\end{array}$ & $\begin{array}{l}\text { GapDH } \\
\text { ACTB }\end{array}$ & 0.031 & 0.020 & $\begin{array}{l}0.011 \\
0.032\end{array}$ \\
\hline $\begin{array}{l}\text { Diseased } \\
\text { Tissue }\end{array}$ & $\begin{array}{l}\text { ACTB } \\
\text { GapDH }\end{array}$ & 0.056 & 0.057 & $\begin{array}{l}0.019 \\
0.068\end{array}$ \\
\hline $\begin{array}{l}\text { Monolayer } \\
\text { Culture }\end{array}$ & $\begin{array}{l}\text { GapDH } \\
\text { SDHA }\end{array}$ & 0.059 & 0.085 & $\begin{array}{l}0.020 \\
0.062\end{array}$ \\
\hline $\begin{array}{l}\text { Collagen } \\
\text { Gel }\end{array}$ & $\begin{array}{l}\text { GapDH } \\
\text { SDHA }\end{array}$ & 0.017 & 0.013 & $\begin{array}{l}0.006 \\
0.020\end{array}$ \\
\hline All Samples & $\begin{array}{l}\text { GapDH } \\
\text { ACTB }\end{array}$ & 0.127 & 0.048 & $\begin{array}{l}0.050 \\
0.072\end{array}$ \\
\hline
\end{tabular}

Coefficients for tissue samples (tendon, cartilage and bone), developing tendon, diseased tendon, monolayer culture and 3D collagen gels. 


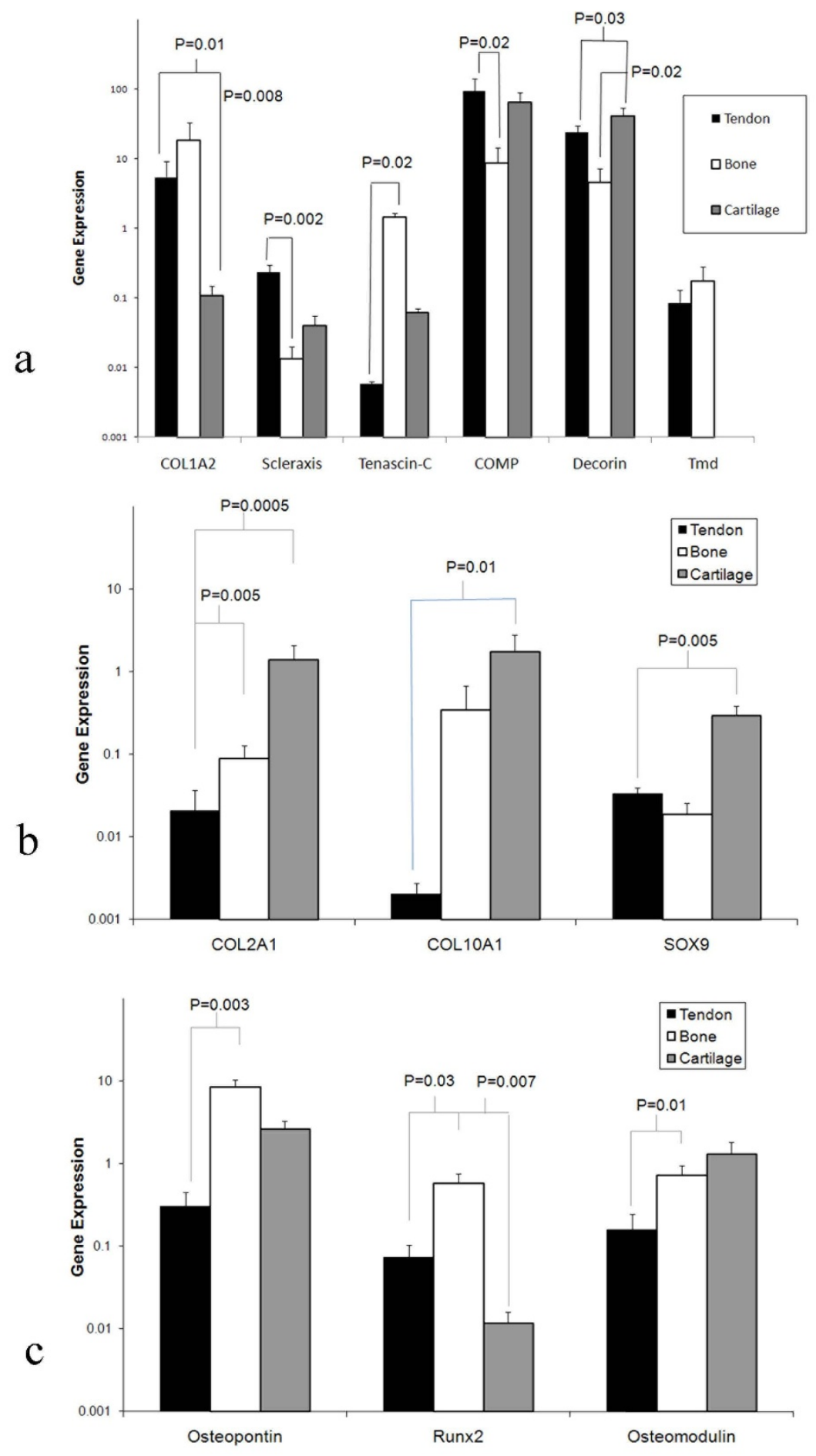

Figure I

Gene expression of normal tendon, bone and cartilage samples. (a) Gene expression of COLIA2, scleraxis, tenascinC, COMP and decorin in matched samples of tendon, cartilage and bone harvested from normal adult horses. (b) Gene expression of COL2AI, COLIOAI and SOX9 in matched samples of tendon, cartilage and bone harvested from normal adult horses. Relative gene expression data is represented graphically as log transformed values. $\mathrm{P}$ values were generated using a mixed effects linear regression model to allow for clustering within individual donors. (c) Gene expression of osteopontin, osteonectin and osteomodulin in matched samples of tendon, cartilage and bone harvested from normal adult horses. 

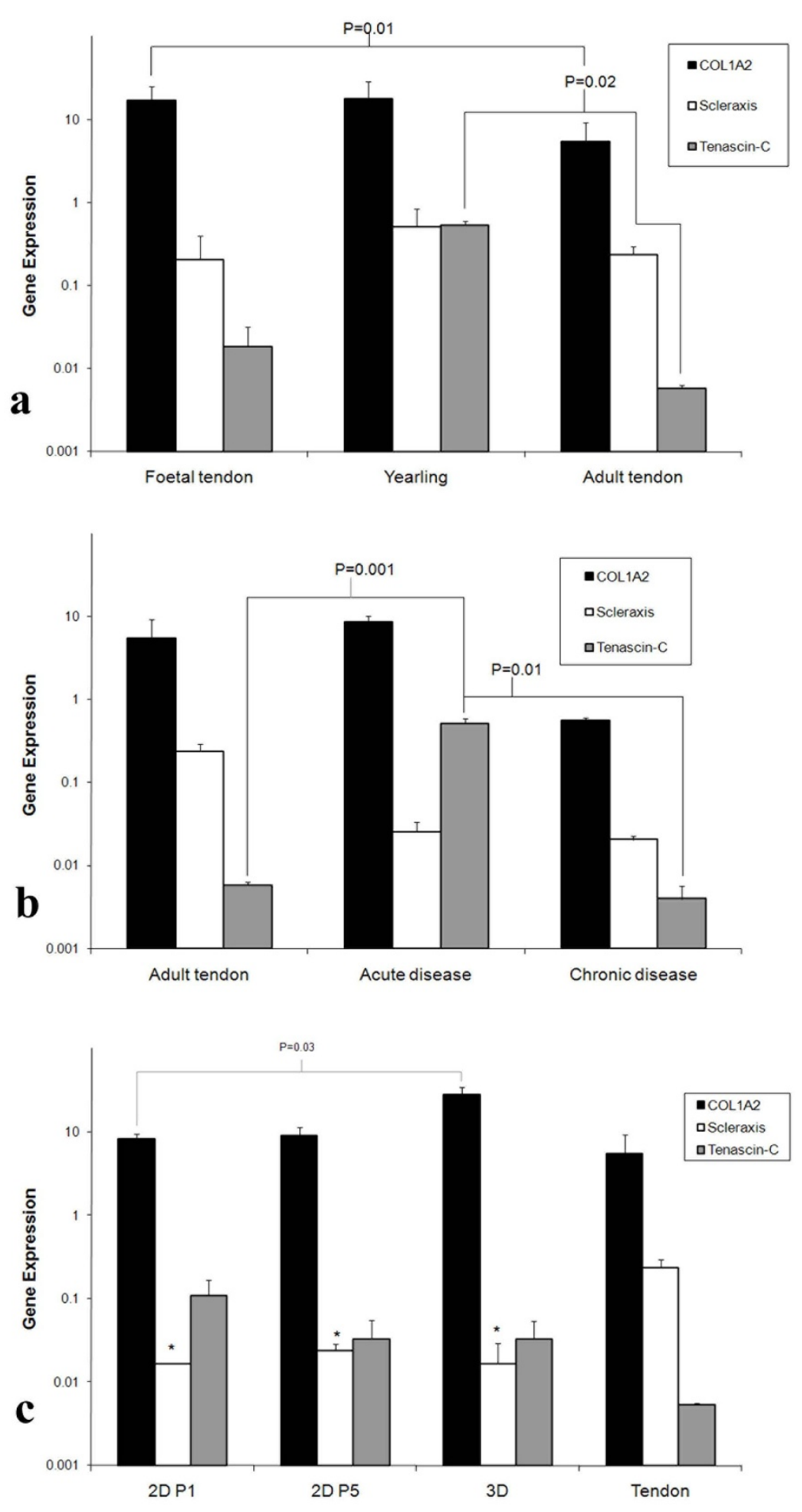

Figure 2

Gene expression of developing and diseased tendon and in vitro gene expression. (a) Gene expression of COLIA2, scleraxis, tenascin-C in SDFT collected from foetuses, yearlings and adults. (b) Gene expression of COLIA2, scleraxis, tenascin- $C$ in acute and chronic disease in comparison to normal adult tendon. (c) Gene expression of COLIA2, scleraxis, tenascin- $C$ in $2 D$ and $3 D$ in vitro culture in comparison to normal adult tendon. (2D PI = passage I monolayer culture, 2D P5 = passage 5 monolayer culture, $3 \mathrm{D}=$ tendon fibroblasts cultured in collagen gels). $\mathrm{P}$ values were generated using a two sample student's t-test for normally distributed log transformed data. 


\section{Cell culture samples Monolayer cell culture}

Scleraxis gene expression was decreased compared to normal adult tendon at passage 1 of monolayer culture of tendon fibroblasts and this significant decrease was maintained at passage $5(\mathrm{P}=0.002$ and $\mathrm{P}=0.004$ respectively) (Figure. 2c). No significant differences in COL1A2 and tenascin-C expression were identified between normal tissue and the 2D in vitro culture systems. Tenomodulin gene expression levels were not detectable in the in vitro cells.

\section{Three dimensional cell culture in collagen gels}

Placing tendon fibroblasts into a three dimensional collagen matrix resulted in increased expression of type I collagen $(P=0.03)$ compared to passage one monolayer cells. No significant difference was identified between levels of COL1A2 and tenascin-C expression by 3D cultured tendon fibroblasts and normal adult tendon. However, 3D cultured tendon fibroblasts showed significantly reduced expression of scleraxis $(\mathrm{P}=0.03)$ in comparison to normal adult tendon (Figure $2 \mathrm{c}$ ).

\section{Discussion}

This study has confirmed that a panel of 'marker' genes are required to identify tendon cell phenotype from other mesenchymal tissues. The matched adult samples of tendon, cartilage and bone show the tensional SDFT to express high levels of COL1A2 and scleraxis and low levels of tenascin-C in comparison to the other tissues. Bone also expresses high levels of COL1A2 but contrastingly low levels of scleraxis and high levels of tenascin-C. In contrast, cartilage expresses moderate amounts of COL1A2, scleraxis and tenascin-C. Tendon regions with a fibrocartilagenous phenotype that are subjected to compressive loads have been shown to have to have higher levels of tenascin-C [35-37], for example at the myotendinous and osteotendinous junctions [38]. Low levels of tenascin- $\mathrm{C}$ within the mid-body of the normal equine SDFT identified in the current study are likely to be a reflection of the tensile loads placed on this region of the tendon. The presence of scleraxis within equine cartilage may be a consequence of the inclusion of the perichondrium in the samples cartilage, a tissue that is derived from scleraxis expressing cells [39].

Scleraxis has been described as being an important marker of tendon neoformation however, there is currently no evidence that scleraxis can induce tendon neoformation [40]. Murchison et al (2007) clearly demonstrated the importance of scleraxis as a transcription factor during tendon development with scleraxis null mutants exhibiting severe defects in the force transmitting tendons. It has been suggested that scleraxis is important in directing condensations of tendon progenitor cells to form the force transmitting tendons [26]. The current experiments did not identify any significant increase in levels of scleraxis expression in mid-gestational foetal tendons compared to normal adult tendons. It is possible that once the tendon phenotype is established during development there is no further change in scleraxis expression. Alternatively, translational control of the protein may differ between developing and adult tendons. Scleraxis expression showed no significant difference between normal and diseased tendons.

Tendon samples collected from horses with naturally occurring acute tendinopathy of the SDFT did not show a significant increase in COL1A2, this may be a result of the large range in expression levels in the normal adult tendon samples, leading to large standard errors. In man, increased expression of type I collagen has been a consistent finding in acute tendinopathy [41]. Tenascin- $\mathrm{C}$ was significantly increased in the acutely diseased samples; this is consistent with the appearance of tenascin-C during the inflammatory phases of wound healing $[17,21]$.

Increased type-I collagen has been reported in chronic degenerate Achilles tendinopathy $[42,43]$ this is at variance with the findings of the current study that identified no significant difference between gene expression of COL1A2 in normal adult tendon and tendinopathy of the SDFT of more than $6 \mathrm{mths}$ duration in the horse. This may reflect differences in clinical condition between painful degenerate Achilles tendons and healed non-painful chronic tendinopathy of the equine SDFT. Levels of tenascin-C mRNA from chronic tendinopathy were not significantly different from normal adult SDFT demonstrating that levels of tenascin-C may only increase transiently in acute injury then to return to normal levels. These findings are at variance with some of the human literature describing degenerate tendons $[8,18]$ where increased tenascin-C may be associated with round cells and a more fibrocartilaginous phenotype or a different disease state.

Monolayer culture of tendon fibroblasts provides a simple method to study cell phenotype. Recent investigations have highlighted significant differences in cellular gene expression in monolayer compared with three dimensional cultures [44]. The gene expression profile of tendon fibroblasts in monolayer culture has recently been shown to alter with progressive passaging [45]. The current experiments have highlighted further differences between monolayer tendon fibroblasts and those found in adult tendon. Scleraxis expression is decreased at both passage one and five in monolayer cultures of tendon fibroblasts hence, neither have a gene expression profile that recapitulates what is found in normal tendon. Three dimensional cell culture methods are thought to more closely 
mimic the in vivo cellular environment $[30,44]$. Unfortunately whilst increasing the expression of COL1A2 in agreement with the work of others [46] expression of scleraxis was not retained when these cells were cultured in three dimensional collagen gels. The in vitro models used in the current study did not fully recreate the adult tendon phenotype. Further work is warranted to identify a culture system that more closely resembles adult tendon. Recently embryonic tendon fibroblasts cultured in a three dimensional fibrin gel [47] were able to maintain a tendon developmental phenotype in the fibrin gel as defined by electron microscopy. Other three dimensional culturing systems have been extensively investigated biomechanically [9] however, the gene expression of these alternative systems has yet to be reported. Clearly, the importance of recreating the transcriptomic profile of normal tendon relative to the functional properties of the engineered tissue requires further evaluation.

The two methods of reference gene stability assessment were in agreement for all experiments carried out in this study, this is concordant with previous findings [48]. Interestingly GapDH was identified as one of the most stable reference genes in vitro while Normfinder found ACTB to be the most stable reference gene when comparing normal and diseased tendons.

\section{Conclusion}

As no single molecular marker was capable of discriminating tendon from both bone and cartilage in the current study it is recommended that multiple genes are used to identify tenogenic differentiation. The current experiments would suggest high expression of COL1A2 and scleraxis and low expression of tenascin-C are most representative of the normal adult tendon phenotype. Furthermore, this work refutes the use of tenomodulin as a good marker of equine tendon fibroblasts as similar levels were identified in both tendon and bone. A genome wide screen may in the future identify specific markers of tendon phenotype. Whether they are maintained in cultured fibroblasts will also need to be determined.

\section{Competing interests}

The authors declare that they have no competing interests.

\section{Authors' contributions}

SET carried out the experimental work, participated in the sequence alignment and statistical analyses and drafted the manuscript. LCM participated in the sequence alignment. DNC and AVT participated in reference gene normalisation. GP helped perform statistical analysis. PDC and RKWS conceived the study, and participated in its design and coordination and helped to draft the manuscript. All authors read and approved the final manuscript.

\section{Additional material}

\section{Additional file 1}

Raw Ct values of reference genes of all samples. The data provided represent the cycle thresholds of the three reference genes used in the data analysis.

Click here for file

[http://www.biomedcentral.com/content/supplementary/14712474-10-27-S1.docx]

\section{Acknowledgements}

S.E. Taylor's Research Training Scholarship is generously funded by the Horserace Betting Levy Board. Thank you to Elizabeth Barr for the design of the osteomodulin and Runx2 primers and to Dr Emma Humphries for the design of the SDHA primer.

\section{References}

I. McCormick A, Charlton J, Fleming D: Assessing health needs in primary care. Morbidity study from general practice provides another source of information. BMJ (Clinical research ed) 1995, 3 I 0(6993): I 534

2. Dowling BA, Dart AJ, Hodgson DR, Smith RK: Superficial digital flexor tendonitis in the horse. Equine veterinary journal 2000 , 32(5):369-378.

3. Kasashima Y, Takahashi T, Smith RK, Goodship AE, Kuwano A, Ueno T, Hirano S: Prevalence of superficial digital flexor tendonitis and suspensory desmitis in Japanese Thoroughbred flat racehorses in 1999. Equine veterinary journal 2004, 36(4):346-350.

4. Patterson-Kane JC, Firth EC: The pathobiology of exerciseinduced superficial digital flexor tendon injury in Thoroughbred racehorses. Vet $j 2008$ in press.

5. Wang JH: Mechanobiology of tendon. Journal of biomechanics 2006, 39(9): I563-1582.

6. Dyson S]: Medical management of superficial digital flexor tendonitis: a comparative study in 219 horses (1992-2000). Equine veterinary journal 2004, 36(5):4I5-4I9.

7. Richardson LE, Dudhia J, Clegg PD, Smith R: Stem cells in veterinary medicine - attempts at regenerating equine tendon after injury. Trends in biotechnology 2007, 25(9):409-4l6.

8. Riley G: Tendinopathy - from basic science to treatment. Nature clinical practice 2008, 4(2):82-89.

9. Butler DL, Juncosa-Melvin N, Boivin GP, Galloway MT, Shearn IT, Gooch C, Awad H: Functional tissue engineering for tendon repair: A multidisciplinary strategy using mesenchymal stem cells, bioscaffolds, and mechanical stimulation. J Orthop Res 2008, 26(I): I-9.

10. Wang QW, Chen ZL, Piao YJ: Mesenchymal stem cells differentiate into tenocytes by bone morphogenetic protein (BMP) 12 gene transfer. Journal of bioscience and bioengineering 2005, I00(4):418-422.

II. Barbero A, Ploegert S, Heberer M, Martin I: Plasticity of clonal populations of dedifferentiated adult human articular chondrocytes. Arthritis and rheumatism 2003, 48(5): I3। 5- I325.

12. Riley GP: Gene expression and matrix turnover in overused and damaged tendons. Scandinavian journal of medicine \& science in sports 2005, I 5(4):24|-25I.

13. Clegg PD, Strassburg S, Smith RK: Cell phenotypic variation in normal and damaged tendons. International journal of experimental pathology 2007, 88(4):227-235.

14. Dahlgren LA, Brower-Toland BD, Nixon AJ: Cloning and expression of type III collagen in normal and injured tendons of horses. American journal of veterinary research 2005, 66(2):266-270.

15. Eriksen HA, Pajala A, Leppilahti J, Risteli J: Increased content of type III collagen at the rupture site of human Achilles tendon. J Orthop Res 2002, 20(6): I352-I357.

16. Molloy TJ, Wang Y, Horner A, Skerry TM, Murrell GA: Microarray analysis of healing rat Achilles tendon: evidence for gluta- 
mate signaling mechanisms and embryonic gene expression in healing tendon tissue. J Orthop Res 2006, 24(4):842-855.

17. Sharma $P$, Maffulli $N$ : Tendon injury and tendinopathy: healing and repair. J Bone Joint Surg Am 2005, 87(I): 187-202.

18. Riley GP, Harrall RL, Cawston TE, Hazleman BL, Mackie EJ: Tenascin- $C$ and human tendon degeneration. The American journal of pathology 1996, I49(3):933-943.

19. Ezura Y, Chakravarti S, Oldberg A, Chervoneva I, Birk DE: Differential expression of lumican and fibromodulin regulate collagen fibrillogenesis in developing mouse tendons. The Journal of cell biology 2000, I 5 I (4):779-788.

20. Smith RK, Zunino L, Webbon PM, Heinegard D: The distribution of cartilage oligomeric matrix protein (COMP) in tendon and its variation with tendon site, age and load. Matrix Bio 1997, 16(5):255-27|.

21. Chiquet-Ehrismann R, Tucker RP: Connective tissues: signalling by tenascins. The international journal of biochemistry \& cell biology 2004, 36(6): 1085-1089.

22. Halasz K, Kassner A, Morgelin M, Heinegard D: COMP acts as a catalyst in collagen fibrillogenesis. The Journal of biological chemistry 2007, 282(43):3। I66-3। I73.

23. Docheva $D$, Hunziker EB, Fassler R, Brandau O: Tenomodulin is necessary for tenocyte proliferation and tendon maturation. Mol Cell Biol 2005, 25(2):699-705

24. Shukunami C, Takimoto A, Oro M, Hiraki Y: Scleraxis positively regulates the expression of tenomodulin, a differentiation marker of tenocytes. Dev Biol 2006, 298(I):234-247.

25. Zhang G, Ezura Y, Chervoneva I, Robinson PS, Beason DP, Carine ET, Soslowsky LJ, lozzo RV, Birk DE: Decorin regulates assembly of collagen fibrils and acquisition of biomechanical properties during tendon development. Journal of cellular biochemistry 2006 98(6): 1436-1449.

26. Murchison ND, Price BA, Conner DA, Keene DR, Olson EN, Tabin C], Schweitzer R: Regulation of tendon differentiation by scleraxis distinguishes force-transmitting tendons from muscleanchoring tendons. Development (Cambridge, England) 2007, I34(I4):2697-2708

27. Schweitzer R, Chyung JH, Murtaugh LC, Brent AE, Rosen V, Olson EN, Lassar A, Tabin C]: Analysis of the tendon cell fate using Scleraxis, a specific marker for tendons and ligaments. Development (Cambridge, England) 200I, I 28(19):3855-3866.

28. Bi Y, Ehirchiou D, Kilts TM, Inkson CA, Embree MC, Sonoyama W, L $\mathrm{L}$, Leet $\mathrm{Al}$, Seo BM, Zhang $\mathrm{L}$, et al.: Identification of tendon stem/ progenitor cells and the role of the extracellular matrix in their niche. Nat Med 2007.

29. Ninomiya K, Miyamoto T, Imai J-i, Fujita N, Suzuki T, Iwasaki R, Yagi $M$, Watanabe $S$, Toyama $Y$, Suda T: Osteoclastic activity induces osteomodulin expression in osteoblasts. Biochemical and biophysical research communications 2007, 362(2):460-466.

30. Garvin J, Qi J, Maloney M, Banes AJ: Novel System for Engineering Bioartificial Tendons and Application of Mechanical Load. Tissue Engineering 2003, 9(5):967-979.

31. Reno C, Marchuk L, Sciore P, Frank CB, Hart DA: Rapid isolation of total RNA from small samples of hypocellular, dense connective tissues. BioTechniques 1997, 22(6): 1082-1086.

32. Clements DN, Vaughan-Thomas A, Peansukmanee S, Carter SD, Innes JF, Ollier WE, Clegg PD: Assessment of the use of RNA quality metrics for the screening of articular cartilage specimens from clinically normal dogs and dogs with osteoarthritis. American journal of veterinary research 2006, 67(8): 1438-I 444.

33. Vandesompele J, De Preter K, Pattyn F, Poppe B, Van Roy N, De Paepe A, Speleman F: Accurate normalization of real-time quantitative RT-PCR data by geometric averaging of multiple internal control genes. Genome biology 2002, 3(7):RESEARCH0034.

34. Andersen $C L$, Jensen JL, Orntoft TF: Normalization of real-time quantitative reverse transcription-PCR data: a model-based variance estimation approach to identify genes suited for normalization, applied to bladder and colon cancer data sets. Cancer research 2004, 64(I 5):5245-5250.

35. de Palma L, Marinelli M, Meme L, Pavan M: Immunohistochemistry of the enthesis organ of the human Achilles tendon. Foot \& ankle international/American Orthopaedic Foot and Ankle Society [and] Swiss Foot and Ankle Society 2004, 25(6):4|4-4I8.
36. Mehr D, Pardubsky PD, Martin JA, Buckwalter JA: Tenascin-C in tendon regions subjected to compression. J Orthop Res 2000, 18(4):537-545.

37. Vogel KG, Keller EJ, Lenhoff RJ, Campbell K, Koob TJ: Proteoglycan synthesis by fibroblast cultures initiated from regions of adult bovine tendon subjected to different mechanical forces. European journal of cell biology 1986, 4 I (I): I02-I I2

38. Jarvinen TA, Kannus $P$, Jarvinen TL, Jozsa $L$, Kalimo $H$, Jarvinen $M$ : Tenascin- $C$ in the pathobiology and healing process of musculoskeletal tissue injury. Scandinavian journal of medicine \& science in sports 2000, I0(6):376-382.

39. Asou Y, Nifuji A, Tsuji K, Shinomiya K, Olson EN, Koopman P, Noda $M:$ Coordinated expression of scleraxis and Sox 9 genes during embryonic development of tendons and cartilage. Orthop Res 2002, 20(4):827-833.

40. Aslan H, Kimelman-Bleich N, Pelled G, Gazit D: Molecular targets for tendon neoformation. The Journal of clinical investigation 2008 , I I 8(2):439-444.

41. de Mos M, van El B, DeGroot J, Jahr H, van Schie HT, van Arkel ER, Tol H, Heijboer R, van Osch G], Verhaar JA: Achilles tendinosis: changes in biochemical composition and collagen turnover rate. The American journal of sports medicine 2007, 35(9): I549-I556.

42. Alfredson $\mathrm{H}$, Lorentzon $M$, Backman S, Backman A, Lerner UH cDNA-arrays and real-time quantitative PCR techniques in the investigation of chronic Achilles tendinosis. J Orthop Res 2003, 2 I (6):970-975

43. Ireland D, Harrall R, Curry V, Holloway G, Hackney R, Hazleman B, Riley G: Multiple changes in gene expression in chronic human Achilles tendinopathy. Matrix Biol 200I, 20(3):159-169.

44. Sawaguchi N, Majima T, Iwasaki N, Funakoshi T, Shimode K, Onodera T, Minami A: Extracellular matrix modulates expression of cell-surface proteoglycan genes in fibroblasts. Connective tissue research 2006, 47(3): I 41 - I 48.

45. Yao L, Bestwick CS, Bestwick LA, Maffulli N, Aspden RM: Phenotypic drift in human tenocyte culture. Tissue Eng 2006, I 2(7): 1843-1849.

46. Zhang L, Tran N, Chen HQ, Kahn C], Marchal S, Groubatch F, Wang $X$ : Time-related changes in expression of collagen types $I$ and III and of tenascin-C in rat bone mesenchymal stem cells under co-culture with ligament fibroblasts or uniaxial stretching. Cell tissue res 2008, 332(I): 10I-109.

47. Kapacee Z, Richardson SH, Lu Y, Starborg T, Holmes DF, Baar K Kadler KE: Tension is required for fibripositor formation. Matrix Biol 2008, 27(4):37I-375.

48. Maccoux LJ, Clements DN, Salway F, Day PJ: Identification of new reference genes for the normalisation of canine osteoarthritic joint tissue transcripts from microarray data. $B M C$ molecular biology 2007, 8:62.

\section{Pre-publication history}

The pre-publication history for this paper can be accessed here:

\section{http://www.biomedcentral.com/1471-2474/10/27/pre} $\underline{\mathrm{pub}}$

Publish with Bio Med Central and every scientist can read your work free of charge

"BioMed Central will be the most significant development for disseminating the results of biomedical research in our lifetime. "

Sir Paul Nurse, Cancer Research UK

Your research papers will be:

- available free of charge to the entire biomedical community

- peer reviewed and published immediately upon acceptance

- cited in PubMed and archived on PubMed Central

- yours - you keep the copyright 